\title{
Two Cases of Orbital Blowout Fractures with Extraocular Muscle Entrapment in Children
}

\author{
Hahn Jin Jung, Ji Hwan Kim, Young Kang, and Young-Seok Choi \\ Department of Otorhinolaryngology-Head and Neck Surgery, Chungbuk National University College of Medicine, \\ Chungbuk National University Hospital, Cheongju, Korea
}

\section{소아에서 발생한 외안근 감돈을 동반한 안와 외향 골절 2예}

정한진 · 김지환 · 강 영 · 최영석

충북대학교 의과대학 충북대학교병원 이비인후과학교실

\author{
Received June 26, 2020 \\ Revised July 29, 2020 \\ Accepted August 3, 2020 \\ Address for correspondence \\ Young-Seok Choi, MD, PhD \\ Department of Otorhinolaryngology- \\ Head and Neck Surgery, \\ Chungbuk National University \\ College of Medicine, \\ Chungbuk National University \\ Hospital, 776 1sunhwan-ro, \\ Seowon-gu, Cheongju 28644, Korea \\ Tel $+82-43-269-6157$ \\ Fax $+82-43-265-6157$ \\ E-mail yschoi@chungbuk.ac.kr
}

Orbital blowout fracture is a common result of facial trauma and with the expanded use of endoscopy in orbital blowout fracture surgery, otolaryngologists are participating more often blowout fracture surgery. Because orbital blowout fracture may result in sequelae such as diplopia and enophthalmos, proper diagnosis and timing of repair are crucial. Orbital blowout fracture with extraocular muscle entrapment is uncommon and almost exclusively seen in children. It needs emergent release of entrapped muscle to prevent permanent sequelae (e.g., diplopia). The authors experienced two cases of orbital blowout fracture with extraocular muscle entrapment and had good surgical results without any sequelae. We report these cases with a review of the literature.

Korean J Otorhinolaryngol-Head Neck Surg 2020;63(11):533-6

Key Words Diplopia · Facial trauma $\cdot$ Muscle entrapment $\cdot$ Orbital blowout fracture.

\section{서 론}

안와 외향 골절(orbital blowout fracture)은 외상으로 의한 충격으로 안와 내 압력이 급격히 상승되어 안와 내벽 또는 하벽 부위에 골절이 발생하는 질환으로, 전체 안면골 골절 중 18 50\%를 차지할 정도로 그 빈도가 높은 골절이다. ${ }^{1)}$ 최근 영상학적 진단 방법의 발전, 수술 기술 및 도구의 발전, 그리 고 재건을 위한 인공 물질의 개발 등으로 심한 골절의 경우 에도 훌륭한 수술 후 결과를 나타내는 경우가 많다. ${ }^{2}$ 하지만 주로 소아에서 많이 발생한다고 알려진 외안근의 감돈(entrapment)이 동반된 안와 외향 골절에 대한 보고는 많지 않 으며, 진단과 수술 시기가 늦어지면 영구적인 복시 등의 후유

This is an Open Access article distributed under the terms of the Creative Commons Attribution Non-Commercial License (https://creativecommons.org/licenses/by-nc/4.0) which permits unrestricted non-commercial use, distribution, and reproduction in any medium, provided the original work is properly cited.
증이 남을 수 있기 때문에 신속한 진단과 치료가 필수적이다. 저자들은 최근 소아에서 발생한 외안근의 감돈을 동반한 안 와 외향 골절 2예를 경험하였고, 후유증 없이 좋은 수술적 치 료 결과를 얻었기에, 이를 기존의 문헌 고찰과 함께 보고하는 바이다.

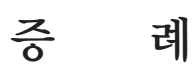

Case 1

15세 남아가 축구를 하다가 우안에 공을 맞은 이후 생긴 복시로 응급실에 내원하였다. 환아는 어지럼증과 오심 및 두 통을 호소하였으며, 시력은 정상이었다. 복시는 우측 측방을 주시할 때 있었으며, 안구 운동 검사에서 우측 및 좌측 주시 시 우안의 제한되는 모습이 관찰되었다. 강제 견인 검사(forced duction test)에서 우측 외전이 되지 않아 내직근의 감돈이 
의심되었다. 안면부 전산화단층촬영상 우측 안와 내벽 외향 골절과 함께 내직근과 연부조직의 감돈이 의심되는 소견이 관찰되었다(Fig. 1A). 수술은 응급으로 수상 당일 시행하였 으며, 전신 마취하에 내시경적 접근법으로 사골동 절제술 후 감돈 부위를 노출한 뒤, green-stick 양상으로 된 lamina papyracea 골절편을 제거함으로써 감돈된 내직근과 연부조 직을 유리한 뒤, 사골동 내 흡수성 코 패킹(Nasopore ${ }^{\circledR}$ Forte $4 \mathrm{~cm}$; Polyganics, Groningen, the Netherlands)을 삽입하 였다. 수술 후 강제 견인 검사에서 안구 운동 제한이 없음을 확인하였으며, 수술 직후 안면부 전산화단층촬영으로 내직 근이 감돈 없이 제자리에 위치함을 확인하였다(Fig. 1B). 수 술 직후 복시는 호전되었으며, 안구 운동 검사에서도 정상 소 견을 보였다. 현재 7 개월 경과한 상태로 특별한 후유증 없이 경과 관찰 중이다.

\section{Case 2}

5세 남아가 넘어지면서 우안 주위를 부딪친 이후 복시와 구토를 주소로 응급실로 내원하였다. 이학적 검사에서 상방 주시 시 우안 통증과 복시가 있었으며, 안구 운동 검사에서 상방, 하방 주시 시 우안의 제한을 보였다. 그외 안압, 시력 등 의 검사에서는 이상 소견을 보이지 않았다. 강제 견인 검사는 협조 불가로 시행하지 못하였다. 안면부 전산화단층촬영에서 우측 안와 하벽 외향 골절과 안구 연부조직 일부가 골절된 파편에 감돈된 것이 의심되었다(Fig. 2A). 수술은 수상 당일
응급으로 시행하였으며, 경결막 절개를 통해 접근하여 하직 근과 안와 지방이 감돈된 부위를 확인하고, 감돈된 조직을 유리한 후에 흡수성 메쉬로 재건술을 시행하였다. 이후 강제 견인 검사를 시행하여 운동 제한이 없는 것을 확인하고 수 술을 종료하였다. 수술 직후 안면부 전산화단층촬영으로 하 직근이 감돈 없이 흡수성 메쉬 위쪽으로 위치함을 확인하였 다(Fig. 2B). 수술 직후 복시는 호전되었으며, 안구 운동 제 한은 완전히 소실되었다. 13 개월 경과한 현재까지 특별한 합 병증 없이 경과 관찰 중이다.

\section{고 찰}

안와 외향 골절은 교통 수단의 발달과 고속화, 산업 재해와 폭력 사고의 증가로 발생 빈도가 높아지는 추세에 있으며, 최 근 비내시경 기술의 발달로 안와 외향 골절 정복술이 이비인 후과 영역에서도 많이 시도되고 있다. 소아의 경우에는 해부 학 및 골조직 특성으로 인해 안와 외향 골절이 드물게 발생하 지만, 골조직이 탄성이 좋고 골막이 두꺼워서 greenstick 양 상의 골절이 흔하며, 이 경우 외안근의 감돈이 동반될 수 있 어서 주의가 필요하다. ${ }^{3)}$ 특히 외안근의 감돈이 동반된 경우 에는 적정 시간 내에 수술적 치료를 통해 교정되지 않을 경우 부분 혹은 영구적인 복시 및 안구 운동 제한 등 후유증이 남 을 수 있기에 신속한 진단 및 치료가 필수적이다. ${ }^{45}$

외안근의 감돈이 동반된 안와 외향 골절의 경우 주로 소아
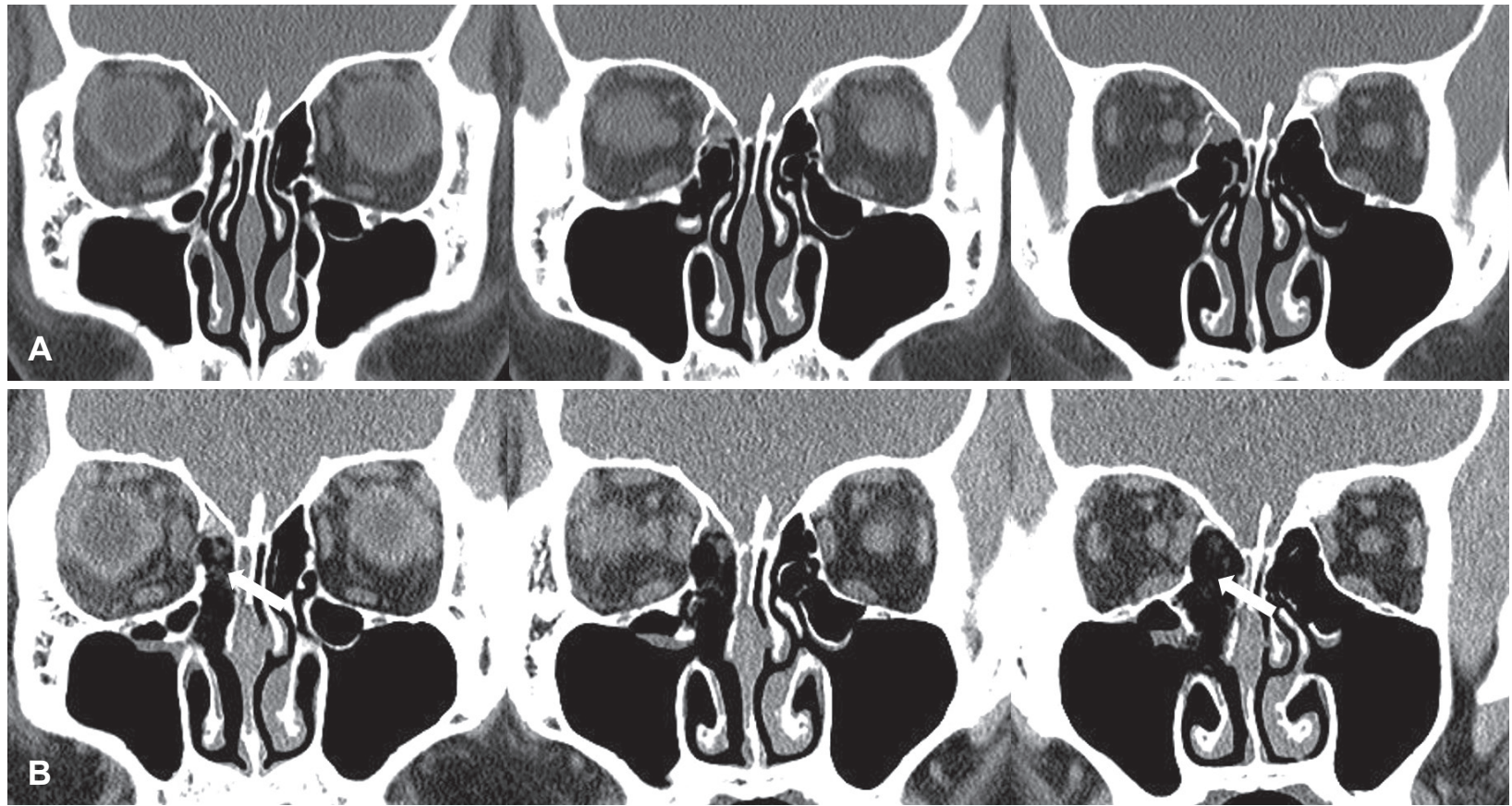

Fig. 1. Facial bone CT images of right medial blowout fracture with medial rectus muscle entrapment. Preoperative images (A). Immediate postoperative images (arrow: Nasopore ${ }^{\circledR}$ Forte; Polyganics, Groningen, the Netherlands) (B). 

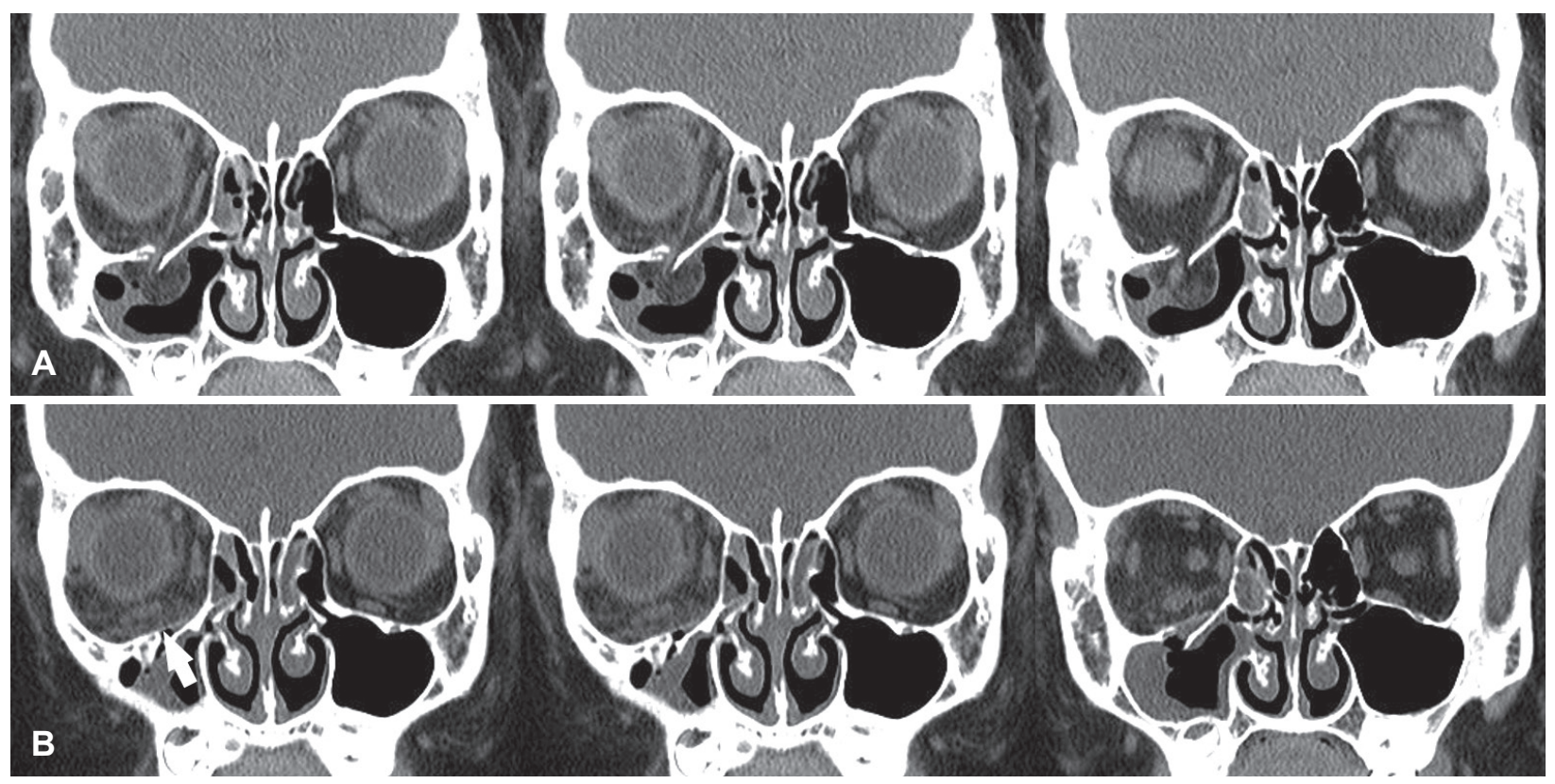

Fig. 2. Facial bone CT images of right inferior blowout fracture with inferior rectus muscle entrapment. Preoperative images (A). Immediate postoperative images (arrow: absorbable mesh) (B).

에서 발생하며, 자세한 병력과 임상 증상 및 증후, 안과적 검 사와 방사선학적 검사로 진단할 수 있다. 대표적인 증상으로 는 안구 운동 장애와 복시가 있다. 외안근이 골절 부위로 감 돈되어 안구 운동 장애가 발생하며, 외안근의 불균형과 이에 따르는 병행했던 양안의 시방향에 변이가 생겨 복시가 발생 한다. ${ }^{6,7)}$ 안구 강제 견인 검사를 하여 외안근 손상 및 감돈 유 무를 확인할 수 있으며, 안면부 전산화단층촬영에서 골절 부 위로의 연부 조직의 감돈이 관찰되기도 한다. ${ }^{2}$ 하지만 대체로 경미한 골절 소견을 보이며 골절부가 작아 안구 조직의 감돈 이 아주 적게 보이거나 거의 보이지 않아 발견하기가 어려울 수 있다. ${ }^{8)}$ 특히 뚜렷한 외상의 연조직 징후가 동반되지 않은 채, 연부 조직의 감돈과 관련된 안구 운동 장애와 통증 등 안구 증상이 나타나는 경우도 있으며 이를 white-eyed 안와 외향 골절이라 하기도 한다.,8) 이에 $\mathrm{Kim}$ 등은 의심이 될 때 에는 경과 관찰을 하기보다는 충분한 설명에 의한 시험적 절 개술이 포함된 수술을 시행하는 것이 좀 더 나은 결과를 얻 을 수 있다고 한 바 있다. 외안근의 감돈 시 동반될 수 있는 안구-심장 반응은 외안근이 골절편 사이에 끼이거나 안구 내 압력이 상승할 때 발생하는 심장 반사로서 구토와 함께 서맥을 일으키고 때론 심정지에 이르기도 하기에 주의를 요 하며, 이러한 안구-심장 반응이 진단이 늦어지게 하는 이유 중 하나가 되기도 한다. ${ }^{10,11}$

일반적으로 안와 외향 골절의 경우 너무 이른 시기에 수술 을 하면 안와 연부 조직의 부종으로 인해 정확한 골절 정복 이 어렵기에, 안구 주위 부종이 빠지고 골절편이 굳기 전인
7 14일 사이에 수술을 하는 것이 보편적이다. ${ }^{12)}$ 하지만 외안 근의 감돈이 동반된 경우에는 48시간 이내의 조기 수술이 수 술 후 복시가 남을 가능성을 줄인다고 알려져 있다.,13) 외안 근이 골절편에 감돈된 경우 외안근의 허혈 손상이 나타나게 되고 48시간 이내에 이를 교정하지 않을 경우 외안근 섬유화 등의 비가역적인 변화가 발생할 수 있기 때문이다. ${ }^{14)}$ Yang 등 ${ }^{15)}$ 은 적절한 수술을 통해 감돈된 외안근이 완전히 정복된다면 24시간 이내에 수술한 환자군과 24 72시간 사이에 수술한 환자군 그리고 72 시간 이후에 수술한 환자군 사이에 수술 성 공률에 있어서 통계학적 차이가 없다고 보고하기도 하였다. 하지만 Kim과 Kang ${ }^{3}$ 은 48시간 이내에 외과적 치료를 받은 환자군은 복시 회복에 평균 1.5 개월 미만의 시간이 필요한 반 면, 수상 후 48시간 이후에 수술을 시행 받은 환자군은 평균 5 개월 이상의 시간이 소요되었다고 보고한 바 있다. 본 증례 들에서는 수상 후 48시간 이내에 응급 수술을 시행하여 2예 모두 영구적인 후유증 없이 좋은 결과를 얻을 수 있었다고 생각된다.

비내시경 기술의 발달로 안와 외향 골절 정복술이 이비인 후과 영역에서 많이 시도되고 있으며, 외안근의 감돈이 동반 된 안와 외향 골절은 흔하지 않다. 정확한 진단과 빠른 수술적 치료가 이루어지지 않을 경우, 복시 등의 영구적인 후유증이 발생할 수 있기에 주의를 요한다.

\section{Acknowledgments}

None. 


\section{Author Contribution}

Conceptualization: Hahn Jin Jung, Young-Seok Choi. Formal analysis: Hahn Jin Jung, Young Kang. Investigation: Hahn Jin Jung, Young Kang. Methodology: Hahn Jin Jung, Ji Hwan Kim. Project administration: Young-Seok Choi. Supervision: Young-Seok Choi. Visualization: Ji Hwan Kim, Young Kang. Writing — original draft: Hahn Jin Jung, Ji Hwan Kim. Writing - review \& editing: YoungSeok Choi.

\section{ORCID}

Young-Seok Choi https://orcid.org/0000-0001-5139-9830

\section{REFERENCES}

1) Chen CT, Chen YR. Update on orbital reconstruction. Curr Opin Otolaryngol Head Neck Surg 2010;18(4):311-6.

2) Shim WS, Jung HJ. Management of orbital blowout fractures: ENT Surgeron's perspective. J Rhinol 2019;26(2):65-74

3) Kim NH, Kang SJ. Correlation between the time to surgery and that to recovery from postoperative diplopia based on a singlecenter, retrospective experience: A case series of 11 patients. Arch Plast Surg 2014;41(5):486-92.

4) Jordan DR, Allen LH, White J, Harvey J, Pashby R, Esmaeli B. Intervention within days for some orbital floor fractures: The whiteeyed blowout. Ophthalmic Plast Reconstr Surg 1998;14(6):379-90.

5) Hammond D, Grew N, Khan Z. The white-eyed blowout fracture in the child: Beware of distractions. J Surg Case Rep 2013;2013(7): rjt054.

6) Chi MJ, Ku M, Shin KH, Baek S. An analysis of 733 surgically treated blowout fractures. Ophthalmologica 2010;224(3):167-75.

7) Emery JM, Noorden GK, Sclernitzauer DA. Orbital floor fractures: Long-term follow-up of cases with and without surgical repair. Trans Am Acad Ophthalmol Otolaryngol 1971;75(4):802-12.

8) Parbhu KC, Galler KE, Li C, Mawn LA. Underestimation of soft tissue entrapment by computed tomography in orbital floor fractures in the pediatric population. Ophthalmology 2008;115(9): $1620-5$.

9) Kim MJ, Kwon JH, Kim JS, Park TJ. A case of white-eyed blowout fracture. Korean J Otorhinolaryngol-Head Neck Surg 2019;62(8): 462-4.

10) Kim BB, Qaqish C, Frangos J, Caccamese JF Jr. Oculocardiac reflex induced by an orbital floor fracture: Report of a case and review of the literature. J Oral Maxillofac Surg 2012;70(11):2614-9.

11) Jackson BF. Orbital trauma, bradycardia, and vomiting: Trapdoor fracture and the oculocardiac reflex: A case report. Pediatr Emerg Care 2010;26(2):143-5.

12) Kwon JH, Moon JH, Kwon MS, Cho JH. The differences of blowout fracture of the inferior orbital wall between children and adults. Arch Otolaryngol Head Neck Surg 2005;131(8):723-7.

13) Liao JC, Elmalem VI, Wells TS, Harris GJ. Surgical timing and postoperative ocular motility in type B orbital blowout fractures. Ophthalmic Plast Reconstr Surg 2015;31(1):29-33.

14) Wei LA, Durairaj VD. Pediatric orbital floor fractures. J AAPOS 2011;15(2):173-80.

15) Yang JW, Woo JE, An JH. Surgical outcomes of orbital trapdoor fracture in children and adolescents. J Craniomaxillofac Surg 2015;43(4):444-7. 